\title{
GROWTH, YIELD, CARBON FIXATION AND ECONOMICS OF RUBBER CULTIVATION IN SRI LANKA
}

\author{
BY \\ ENOKA SHIROMALEE MUNASINGHE
}

Thesis submitted to the University of Sri Jayewardenepura for the award of the

Degree of Doctor of Philosophy in Forestry 


\section{DECLARATION}

The work described in this thesis was carried out by me under the supervision of Dr. (Mrs) U.A.D.P. Gunawardena of the University of Sri Jayewardenepura and Dr. V.H.L. Rodrigo of the Rubber Research Institute of Sri Lanka and a report on this has not been submitted in whole or in part to any university or any institution for another Degree/Diploma.

Signature: $\ldots \ldots \ldots \ldots \ldots$

Name : Enoka Shiromalee Munasinghe

Date : 2.4. 0...………. 


\section{SUPERVISORS' CERTIFICATION}

We certify that this thesis meets the required standard for the Degree of Doctor of Philosophy.

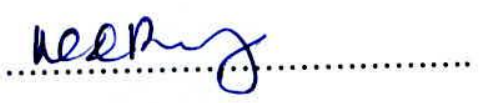

Dr. (Mrs.) U. A. D. P. Gunawardena

Dept. of Forestry \& Environmental Science

University of Sri Jayewardenepura

Nugegoda

Sri Lanka

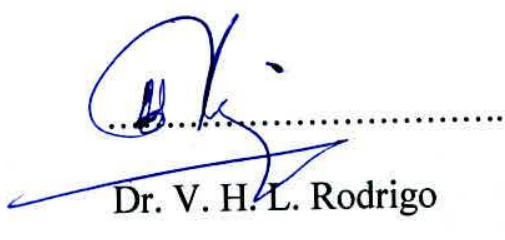

Dept. of Biochemistry and Physiology Rubber Research Institute of Sri Lanka Agalawatta

Sri Lanka

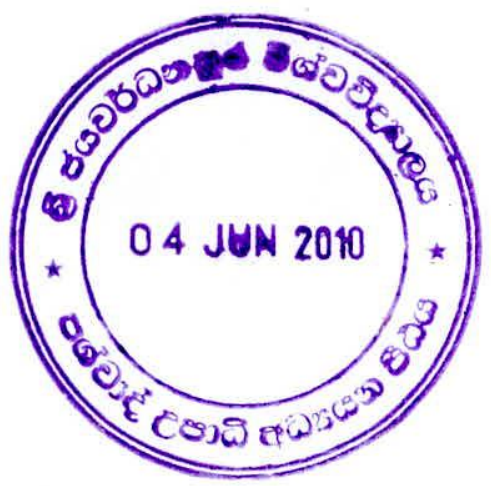


"DEDICATED TO THE MEMORY OF ONE I LOST" 


\section{TABLE OF CONTENTS}

\section{Page}

TABLE OF CONTENTS

LIST OF TABLES $\quad$ ix

LIST OF FIGURES $\quad$ xi

LIST OF PLATES $\quad$ XV

ABBREVIATIONS $\quad$ xvi

ACKNOWLEDGEMENT $\quad$ xix

$\begin{array}{ll}\text { ABSTRACT } & \mathrm{xxi}\end{array}$

CHAPTER 1 : BACKGROUND 1

CHAPTER 2 : LITERATURE REVIEW $\quad 6$

2.1 Importance of rubber cultivation $\quad 6$

2.2 Development of rubber industry 9

$\begin{array}{lll}2.3 & \text { Morphology of rubber } & 10\end{array}$

2.4 Climatic requirements of rubber 11

2.5 Mathematical approach to quantify the growth and yield of rubber $\quad 12$

2.6 Rubber cultivation in Sri Lanka 13

$\begin{array}{lll}2.7 & \text { Role of carbon in greenhouse effect } & 17\end{array}$

2.8 International interventions in climate change 19

$2.9 \quad$ Sri Lankan potential in carbon market $\quad 22$

2.10 Economics of climate change 25

2.11 Economic evaluation 26 
2.12 Economics in sustainable development

2.13 Practical valuation techniques

2.14 Benefit Cost Analysis $\quad 35$

2.15 Implication of Benefit-Cost Analysis in economic analyses 39

2.16 Multicriteria analysis $\quad 43$

2.17 Policy instruments for plantation management 43

2.18 Conceptual framework for rubber cultivation in Sri Lanka $\quad 46$

CHAPTER 3 : GROWTH AND DEVELOPMENT OF RUBBER UNDER 48 DIFFERENT GROWTH CONDITIONS

3.1 Introduction

3.1.1 Importance of growth assessment

3.1.2 Factors underpinning the growth of rubber

3.2 Objective

3.3 Methodology

3.3.1 Study area

3.3.2 Planting materials

3.3.3 Sampling

3.3.4 Assessments

3.3.4.1 Non destructive growth assessments

3.3.4.2 Destructive growth assessments

3.3.4.3 Organic carbon content

3.4 Results

3.4.1 Girth development 
3.4.3 Bark thickness

3.4.4 Wood density

3.4.5 Timber log volume

3.4.5.1 Total timber log volume

3.4.5.2 Sawnable timber log volume

3.4.6.1 Biomass distribution among different aboveground components of the tree

3.4.6.2 Biomass distribution among different belowground components of the tree COMPONENTS OF RUBBER

4.1 Introduction

4.2 Objective 79

4.3 Methodology 80

4.4 Results 87

4.4.1 Ontogenetic changes in tree diameter 87

4.4.2 Ontogenetic height development 89

4.4.3 Ontogenetic variation of latex yield 91

4.4.4 Changes in tree density 
4.4.5 Relationship between timber log volume with diameter and total height of the tree

4.4.6 Relationship between biomass with diameter and total height of the tree

4.4.7 Relationship between carbon content with diameter and total height of the tree

4.4.8 Validation of models developed for total timber, total biomass and total carbon of the tree

4.4.9 Development of yield tables

PLANTATION SECTOR OF SRI LANKA

5.1 Introduction

5.2 Objective

5.3 Methodology

5.3.1 Estimation of costs

5.3.1.1 Inputs and costs of rubber cultivation

5.3.1.2 Inputs and costs of intercrops

5.3.2 Estimation of benefits

5.3.2.1 Estimation of benefits from rubber

5.3.2.2 Estimation of benefits from intercrop

5.3.3 Financial analysis of rubber

5.3.4 Economic analysis of rubber 
$\begin{array}{lll}\text { 5.4.1 Cost of rubber cultivation } & 123\end{array}$

$\begin{array}{ll}\text { 5.4.2 Cost of intercropping } & 126\end{array}$

$\begin{array}{lll}5.4 .3 & \text { Revenue from rubber } & 128\end{array}$

$\begin{array}{ll}\text { 5.4.4 Revenue from intercropping } & 129\end{array}$

5.4.5 Financial analysis of rubber under different scenarios $\quad 132$

5.4.6 Economic analysis of rubber under different scenarios $\quad 138$

$\begin{array}{lll}5.5 & \text { Discussion } & 145\end{array}$

\section{BASED INTERCROPING SYSTEMS IN SMALLHOLDINGS IN}

\section{SRI LANKA}

6.1 Introduction

$\begin{array}{lll}6.2 & \text { Objective } & 154\end{array}$

$\begin{array}{lll}6.3 & \text { Methodology } & 154\end{array}$

$\begin{array}{lll}\text { 6.3.1 Preliminary survey on smallholdings } & 155\end{array}$

6.3.2 Socio economic assessment on the farmers practising three major 157 rubber based intercrops

$\begin{array}{lll}\text { 6.3.3 Statistical analysis of information on smallholdings } & 157\end{array}$

$\begin{array}{lll}6.4 & \text { Results } & 160\end{array}$

6.4.1 Status of the intercropping systems in major rubber growing $\quad 160$ regions

6.4.2 Benefit -Cost analysis of three widely adopted intercropping systems under the smallholder condition 
6.4.3 Socio economic factors underpinning the profitability of three widely adopted rubber based intercrops

6.4.4 Quantification of the effect of key factors governing the profitability

6.5 Discussion

CHAPTER 7 : GENERAL DISCUSSION

7.1 Potential of rubber cultivation for a CDM project

7.2 Importance of growth models in CDM project

7.3 Contribution of rubber cultivation to the economy of Sri Lanka

7.4 Potential changes in the economic lifecycle of rubber

7.5 Proposals for effective implementation of industry needs

CHAPTER 8 : CONCLUSIONS AND FURTHER STUDIES

REFERENCES

APPENDICES

Appendix 1.0 List of Publications and Communications from thesis

Appendix 5.1 Labour and material requirement for initial establishment of rubber

Appendix 5.2 Labour and material requirement during immature period of rubber

Appendix 5.3 Labour and material requirement during mature period of 
rubber

Appendix 5.4 Labour and material requirement for tea cultivation under

rubber

Appendix 5.5 Labour and material requirement for pineapple cultivation

under rubber

Appendix 5.6 Labour and material requirement for banana cultivation

under rubber

Appendix $5.7 \quad$ Carbon prices from various sources

Appendix 5.8 Cost Insurance and Freight (CIF) values of imported

fertilizers

Appendix 5.9 Sectoral, aggregate and primary input conversion factors

used for the conversion of market values to real values in

economic analysis

Appendix 5.10 Cost and material usage of rubber cultivation according to the activity for 30 year period

Appendix 5.11(a) Cost of labour usage in the initial establishment of rubber

Appendix 5.11(b) Cost of material usage in the initial establishment of rubber

Appendix 5.12(a) Cost of labour usage in the maintenance of the unyielding period (immature upkeep) of rubber

Appendix 5.12(b) Cost of material usage in the maintenance of the unyielding period (immature upkeep) of rubber

Appendix 5.13(a) Cost of labour usage in the mature upkeep of rubber

Appendix 5.13(b) Cost of material usage in the mature upkeep of rubber

Appendix 5.14(a) Cost of labour usage in the initial establishment of tea 
Appendix 5.14(b) Cost of material usage in the initial establishment of tea

Appendix 5.14(c) Cost of labour usage in the upkeep of tea during the immature phase of rubber

Appendix 5.14(d) Cost of material usage in the upkeep of tea during the immature phase of rubber

Appendix 5.14(e) Cost of labour usage in the upkeep of tea during the mature phase of rubber

Appendix 5.14(f) Cost of material usage in the upkeep of tea during the mature phase of rubber

Appendix 5.15(a) Cost of labour usage in the upkeep of pineapple during the immature phase of rubber

Appendix 5.15(b) Cost of material usage in the upkeep of pineapple during the immature phase of rubber

Appendix 5.16(a) Cost of labour usage in the upkeep of banana during the immature phase of rubber

Appendix 5.16(b) Cost of material usage in the upkeep of banana during the immature phase of rubber

Appendix 6.1 Questionnaire used to gather the information on rubber based intercropping systems in major rubber growing regions of the country

Appendix 6.2 Questionnaire used to gather the information on rubber based tea, pineapple and banana intercropping practices form smallholders 


\section{LIST OF TABLES}

Table $3.1 \quad$ Percentage distribution of total timber log volume (up to 20

$\mathrm{cm}$ girth) of three mature genotypes of rubber

Table 3.2 Percentage distribution of sawnable timber log volume (up to

$50 \mathrm{~cm}$ girth) of three mature genotypes of rubber

Table 3.3 Organic carbon content in biomass of different components

in a mature tree of Hevea genotype RRIC 100

Table 4.1 Model predicted values of latex rubber, total timber volume,

total biomass and total carbon content in the rubber crop for

Wet and Intermediate zones

Table 5.1 Cost of rubber cultivation on labour and material (Rs./ha)

Table 5.2 Cost of tea cultivation under rubber (Rs./ha) 126

Table 5.3 Cost of pineapple cultivation under rubber (Rs./ha) 127

$\begin{array}{lll}\text { Table 5.4 Cost of banana cultivation under rubber (Rs./ha) } & 128\end{array}$

Table 5.5 Summary of financial analysis of the rubber cultivation under

12 different scenarios

Table 5.6 Summary of economic analysis of the rubber cultivation

under 12 different scenarios

Table 6.1 Scoring criteria used for categorizing data of the

questionnaire based survey

Table 6.2(a) Summary of statistical correlation (Spearman) analysis for

the parametric socio economic factors underpinning the 
profitability of rubber based intercropping systems

Table 6.2(b) Summary of statistical correlation (Spearman) analysis for the parametric technical and land related factors underpinning the profitability of rubber based intercropping systems

Table 6.3(a) Summary of statistical correlation (Pearson) analysis for the socio economic factors underpinning the profitability of rubber based intercropping systems

Table 6.3(b) Summary of statistical correlation (Pearson) analysis for the technical and land related factors underpinning the profitability of rubber based intercropping systems

Table 6.4(a) The average ranks obtained using Kruskal-Wallis test for the problems associated with practising rubber based intercropping systems

Table 6.4(b) The average ranks obtained using Kruskal-Wallis test for the reasons of farmer motivation to rubber based intercropping systems 


\section{LIST OF FIGURES}

$\begin{array}{lll}\text { Figure 2.1 CDM project design structure } & 24\end{array}$

$\begin{array}{lll}\text { Figure 2.2 Dimensions of Environmental Economics } & 28\end{array}$

Figure 2.3 Sustainable development triangle-key elements and 30 interconnections (corners, sides, centre)

Figure 2.4 Categories of economic values attributed to environmental assets

Figure 2.5 Economic value of an environmental good 34

Figure 2.6 Conceptual framework for rubber cultivation in Sri Lanka $\quad 47$

Figure 3.1 Girth (at $150 \mathrm{~cm}$ height) development of rubber tree in 65 genotype RRIC 100

Figure 3.2 Height development of rubber tree in genotype RRIC $100 \quad 66$

Figure 3.3 Variation of bark thickness along the genotype RRIC $100 \quad 67$ tree in the Wet Zone

Figure 3.4 Wood density variation of different tree components of genotype RRIC 100 tree in the Wet Zone

Figure 3.5 Ontogenetic variation of wood density (at $150 \mathrm{~cm}$ height) of genotype RRIC100 in the Wet Zone

Figure 3.6 Percentage biomass distribution in the aboveground components of two mature genotypes

Figüre $3.7 \quad$ Percentage biomass distribution among belowground components of mature RRIC 100 genotype

Figure 4.1 Schematic diagram explaining the process of model 
development

Figure 4.2 Diameter development of rubber tree in Wet and

Intermediate zones of Sri Lanka (genotype RRIC 100)

Figure 4.3 Total height development of rubber tree in Wet and

Intermediate zones of Sri Lanka (genotype RRIC 100)

Figure 4.4 Yield profile of rubber tree in Wet Zone of Sri Lanka

(genotype RRIC 100)

Figure 4.5 Ontogenetic variation of tree density in the Wet Zone of Sri

Lanka (genotype RRIC 100)

Figure 4.6 Relationship of total timber log volume and sawnable timber

log volume (per tree) with the tree diameter (at $150 \mathrm{~cm}$

height) and the total height

Figure 4.7 Relationship of biomass in total timber, total aboveground

biomass, total biomass (per tree) with the tree diameter (at

$150 \mathrm{~cm}$ height) and the total height and total belowground

biomass (per tree) with tree diameter

Figure 4.8 Relationship of carbon in total timber, total aboveground

biomass, carbon in total biomass (per tree) with the tree

diameter (at $150 \mathrm{~cm}$ height) and the total height and, carbon

in total belowground biomass (per tree) with tree diameter

Figure 4.9 The goodness of the fit of the models for total timber volume,

total biomass and total carbon in a different site with mixed genotypes of rubber

Figure 5.1 Cost distribution of rubber cultivation among major activities 
Figure 5.2 Variation of the revenue from latex and scrap rubber with time

Figure 5.3 Variation of the revenue from tea, pineapple and banana with time

Figure 5.4 The sensitivity of the Net Present Value (NPV) of rubber cultivation to the changes in the discount rate

Figure 5.5 The sensitivity of the Net Present Value (NPV) of rubber cultivation to the changes in the market price of latex

Figure 5.6 The sensitivity of the Net Present Value (NPV) of rubber cultivation to the changes in the market price of rubber tree

Figure 5.7 The sensitivity of the Net Present Value (NPV) of rubber cultivation to the changes in the market price of carbon

Figure 5.8 The sensitivity of Net Present Value (NPV) in intercropping systems to the changes in the market price of their produce

Figure 5.9 The sensitivity of the Net Present Value (NPV) of rubber cultivation to the changes in the discount rate under the baseline scenario

Figure 5.10 The sensitivity of the Net Present Value (NPV) of rubber cultivation to the changes in the price of rubber under the baseline scenario

Figure 5.11 The sensitivity of the Net Present Value (NPV) of rubber cultivation to the changes in the price of rubber tree under the baseline scenario

Figure 5.12 The sensitivity of the Net Present Value (NPV) of rubber cultivation to the changes in carbon price under the baseline 
scenario

Figure 5.13 The sensitivity of Net Present Value (NPV) in intercropping systems to the changes in the market price of their produce under the baseline scenario

Figure 6.1 Distribution of smallholders practising rubber based intercrops in rubber growing regions of Sri Lanka

Figure 6.2 Distribution of land area under the cultivation of rubber based intercrops in rubber growing regions of the country

Figure 6.3 Distribution of land size under cultivation of rubber based 162 intercrops in rubber growing regions of the country

Figure 6.4 Availability of different crops as intercrops of rubber 163

Figure 6.5 Management condition of the intercropped lands

Figure 6.6 Profit distribution of three main rubber based intercropping systems

Figure 7.1 Financial viability of rubber plantation with the changes in rotational age in terms of Net Present Value (NPV), Internal Rate of Return (IRR) and Benefit-Cost Ratio (BCR)

Figure 7.2 Financial viability of rubber plantation (including carbon values) with the changes in rotational age in terms of Net Present Value (NPV), Internal Rate of Return (IRR) and Benefit Cost Ratio (BCR) 


\section{LIST OF PLATES}

Plate 2.1 Distribution of the rubber cultivation in different

administrative districts of Sri Lanka.

Plate 3.1 A demonstration on some growth measurements of rubber.

Plate $3.2 \quad$ Destructive growth analysis for timber and biomass. 63

Plate 6.1 Widely adopted rubber based intercropping systems in Sri

Lanka. 
ABBREVIATIONS

\begin{tabular}{|c|c|c|}
\hline ADSL & - & Agriculture Department of Sri Lanka \\
\hline AGBM & - & Aboveground Biomass \\
\hline AGR & - & Absolute Growth Rate \\
\hline ANRPC & - & Association of Natural Rubber Producing Countries \\
\hline BCR & - & Benefit Cost Ratio \\
\hline BGBM & - & Belowground Biomass \\
\hline $\mathrm{BI}$ & - & Renewed bark of base panel of the rubber tree \\
\hline $\mathrm{BM}$ & - & Biomass \\
\hline $\mathrm{BO}$ & - & Virgin bark of base panel of the rubber tree \\
\hline $\mathrm{BCA}$ & - & Benefit Cost Analysis \\
\hline CDM & - & Clean Development Mechanism \\
\hline CER & - & Certified Emission Reduction \\
\hline CIF & - & Cost Insurance and Freight \\
\hline $\mathrm{COP}$ & - & Cost of Production \\
\hline $\mathrm{D}$ & - & Diameter \\
\hline DNA & - & Designated National Authority \\
\hline DOE & - & Designated Operational Entity \\
\hline DS & - & Divisional Secretaries \\
\hline EAD & - & Export Agriculture Department \\
\hline EB & - & Executive Board \\
\hline ERP & - & Eppawala Rock Phosphate \\
\hline
\end{tabular}




\begin{tabular}{|c|c|c|}
\hline ERU & - & Emission Reduction Units \\
\hline ET & - & Emission Trading \\
\hline FD & - & Forest Department \\
\hline G-77 & - & Group of 77 \\
\hline GDP & - & Gross Domestic Production \\
\hline GHG & - & Greenhouse Gas \\
\hline GoSL & - & Government of Sri Lanka \\
\hline $\mathrm{H}$ & - & Height \\
\hline HWP & - & Harvested Wood Products \\
\hline IRR & - & Internal Rate of Return \\
\hline IZ & - & Intermediate Zone \\
\hline JI & - & Joint Implementation \\
\hline LULUCF & - & Land Use Land Use Change and Forestry \\
\hline MC & - & Marginal Cost \\
\hline MDF & - & Medium Density Fibre Board \\
\hline MENR & - & Ministry of Environment and Natural Resources \\
\hline MOP & - & Muriate of Potash \\
\hline MPAHA & - & Ministry of Public Administration and Home Affairs \\
\hline MPI & - & Ministry of Plantation Industries \\
\hline NPV & - & Net Present Value \\
\hline NTFP & - & Non Timber Forest Products \\
\hline PAC & - & Policy Analysis Circle \\
\hline PDD & - & Project Design Document \\
\hline PIN & - & Project Idea Note \\
\hline
\end{tabular}




\begin{tabular}{|c|c|c|}
\hline RDDSL & - & Rubber Development Department of Sri Lanka \\
\hline RDO & - & Rubber Development Officer \\
\hline RGR & - & Relative Growth Rate \\
\hline RP & - & Rock Phosphate \\
\hline RPC & - & Regional Plantation Company \\
\hline RRISL & - & Rubber Research Institute of Sri Lanka \\
\hline RSS & - & Ribbed Smoked Sheets \\
\hline SOC & - & Social Opportunity Cost \\
\hline STFIC & - & Special Task Force Intercropping \\
\hline STPR & - & Social Time Preference Rate \\
\hline TBM & - & Total Biomass \\
\hline TEV & - & Total Economic Value \\
\hline TPD & - & Tapping Panel Dryness \\
\hline TRISL & - & Tea Research Institute of Sri Lanka \\
\hline TSHDA & - & Tea Small Holders Development Authority \\
\hline TSR & - & Technically Specified Rubber \\
\hline UNFCCC & - & United Nations Frame Work Convention on Climate Change \\
\hline WTA & - & Willingness to Accept \\
\hline WTP & - & Willingness to Pay \\
\hline $\mathrm{WZ}$ & - & Wet Zone \\
\hline YAP & - & Years after Planting \\
\hline YPH & - & Yield per Hectare \\
\hline
\end{tabular}




\section{ACKNOWLEDGEMENT}

First and foremost, I wish to express my sincere gratitude to my external supervisor Dr. V.H.L.Rodrigo, Head, Dept. of Biochemistry and Physiology, Rubber Research Institute of Sri Lanka (RRISL) for setting up my study programme and providing invaluable supervision throughout the research. His guidance, intellectual advices, close supervision, endless encouragement and unfailing support far beyond the official level made this effort success. He deserves a special gratitude for the large amount of time allocation in reading the manuscript and the tolerance to my frequent interruptions. It was indeed a privilege to have him as my supervisor.

I am indebted to my internal supervisor, Dr.(Mrs.)U.A.D.P.Gunawardena, Senior Lecturer, Dept. of Forestry and Environmental Science, University of Sri Jayawardenepura (USJ) for her kind supervision, careful perusal of each chapter and invaluable comments provided. Also, she deserves special thanks for her role in the university administrative system by clearing the pathway to pursue my postgraduate study. In particular, the extended period given for the study soothed pressure on me from the disturbances in my personal life.

A special mention must be made of Dr. A. Nugawela, Director RRISL, who was my first research guide in the RRISL for providing me the opportunity to join the institute initially. My thanks are also due to Dr.(Mrs.)W.Wijesuriya of RRISL for her valuable advices and assistance in statistical analyses, staff of the Dept. of Soils and Plant Nutrition of RRISL for helning plant sample analyses, Dept. of Forestry and Environmental Science of USJ for lending instruments for growth measurements and Rubber Development Dept. of Sri Lanka (RDDSL) for providing me necessary information and assistance given to work with smallholders. 
I greatly appreciate the technical assistance provided by Mr. W. Karunathilake, Mr. Y. Jayasekera, Mr. R. Handapangoda, and Mr. S. Randunu of RRISL in field measurements and the smallholder survey. I wish to express my gratitude to Mr. \& Mrs. Ramesh for providing me a portable computer during the period of writing. I am thankful to the managers of Dartonfield, Padukka, Salawa, Hedigalla, Palm garden, Pussella, Pitiyakanda and Kumarawatta estates and smallholders for allowing me to conduct growth assessments in their fields and providing relevant information. Also, I appreciate the service of Mr. K. Gunawardena of Dartonfield Group for providing me necessary information on demand without any delay. I am obliged to my research colleagues in the RRISL, Dr. Iqbal, Ms. Dhammika, Ms. Sagari and Ms. Shashika - they know what for.

I also acknowledge the research grants of the Council for Agricultural Research Policy (No. 12/530/400) and Climate Change Enabling Activity (Phase II) of Ministry of Environment and Natural Resources for the financial support given.

I would like to pay a special tribute to my husband, Aruna, who has been my greatest emotional asset which enabled me to meet this challenge. His patience, understanding, encouragement and sacrifices led my study to success through the life potholes. My mother, Mrs. Kodithuwakku whose ultimate wish has been my success in education, would have been met by this study. I thank her very much for covering my duties at home on my behalf. A special mention must be made of my little daughter, Nethmi for her continuous inspiration, affection and tolerance to my devotion to studies instead of being with her. Also, I am indebted to my little son Nethra, the one mostly neglected by me during the period of study. 


\title{
Growth, yield, carbon fixation and economics of rubber cultivation in Sri
}

\section{Lanka}

\section{Enoka Shiromalee Munasinghe}

\begin{abstract}
Being an industrial crop, rubber (Hevea brasiliensis Muell. Arg.) is exclusively cultivated for income generation though some associated crops in rubber based intercropping systems could partly be used for subsistence. As for any venture, direct and indirect investments made by different stakeholders to promote rubber cultivation in the country are to be justified in financial and economic terms. Obviously, spatial and temporal variability of rubber cultivation with respect to plant growth and yield, management conditions, market flows and stakeholders' perceptions is to be accounted in these financial and economic assessments. Such studies to date have been confined to the general condition prevailed in the plantation sector of Sri Lanka. Therefore, the present study was aimed to assess the financial and economic viability of the rubber cultivation considering its growth in two major agroecological zones: Wet and Intermediate zones, and the potential benefits received from latex, timber/firewood and carbon credits in CDM market under the average management conditions with both sole and intercropping. Further, the study was met to identify the key factors underpinning the profitability of some rubber based intercrops in smallholdings.
\end{abstract}

Ontogenetic variations of tree growth and yield of rubber were quantified through in situ assessments of related parameters and, simple models were derived to explain timber volume, biomass and carbon content in the rubber tree based on easily measurable growth 
indicators such as tree diameter and total height. This information together with market rates/economic values for cost and revenue components of rubber cultivation and three major intercrops: banana, tea and pineapple, is used for financial and economic assessments. The present status of rubber based intercropping systems in the country was assessed through an island wide survey and then, key socio economic factors underpinning the profitability of above mentioned intercrops were identified.

On average, a rubber tree in Wet zone was capable of producing $0.73 \mathrm{~m}^{3}$ of total timber and $0.58 \mathrm{~m}^{3}$ of sawnable timber log volumes, $668 \mathrm{~kg}$ of biomass and fixing $274 \mathrm{~kg}$ of carbon in 30 years. Corresponding values per hectare were $208 \mathrm{~m}^{3}, 166 \mathrm{~m}^{3}, 191 \mathrm{MT}$ and $79 \mathrm{MT}$, respectively. The resultant values in Intermediate zone were $c a .16 \%$ less than those in the Wet zone. As per the guidelines given for forestry based CDM projects, new planting of rubber in Intermediate zone has a potential of trading its $\mathrm{CO}_{2}$ fixed within the trees. Rubber cultivation only for latex and timber was financially viable (at farmer level) with NPV of Rs.1.66 million, IRR of $22 \%$ and BCR of 1.44 . According to economic analyses, rubber cultivations were more viable at national level than the farmer level with NPV of Rs.3.9 million, IRR of $34 \%$ and BCR of 2.32. Inclusion of carbon values and intercrops increased the financial/economic viability by $c a .6 \%$ and $c a$. $60 \%$, respectively. Potential for reducing the rotational age of rubber cultivation was also assessed. Profitability of both banana and tea intercropping with rubber was governed by the cropping intensity and the total land extent of respective crop. Further, type of employment and educational level of the farmer influenced the profitability of banana whilst scarcity of labour was a determinant of the profitability of tea. Measures to be taken for effective adoption of rubber based intercrops and building up CDM projects are proposed. 